\title{
Induction of implantation in the mouse by intrauterine injection of adenosine monophosphate
}

\author{
A. Fernandez-Noval and F. Leroy \\ Human Reproduction Research Unit, St. Pierre Hospital, Free University of Brussels, Belgium
}

Summary. Like cyclic AMP or dibutyryl cyclic AMP, intrauterine administration of AMP (non-cyclic) induced implantation in ovariectomized, progesterone-treated mice.

\section{Introduction}

In lactating or ovariectomized and progesterone-treated mice, the implantation of blastocysts in delay is induced by 'nidatory' oestrogen (Smith \& Biggers, 1968). The intrauterine instillation of cyclic AMP or its dibutyryl derivative (dbcAMP) also stimulates the metabolism and implantation of experimentally delayed blastocysts (Mohla \& Prasad, 1970; Holmes \& Bergström, 1975, 1976; Webb, 1975 ), and it has been suggested (Rosenfeld \& O'Malley, 1970) that the action of 'nidatory' oestrogen is effected by cyclic AMP, perhaps according to the 'second messenger' model (Robison, Butcher \& Sutherland, 1968). However, the results of the experiments of Holmes \& Bergström $(1975,1976)$ and Webb (1975) were evaluated by comparison with controls treated with solvent alone, and animals injected with non-cyclic AMP were not included in the experiments. We therefore investigated the ability of AMP to precipitate implantation in mice.

\section{Materials and Methods}

The presence of a vaginal plug was taken as Day 1 of pregnancy and albino mice of the NMRI strain were ovariectomized without damaging the oviducts on Day 3. From Day 3 until autopsy, all mice were treated daily with a subcutaneous injection of $1 \mathrm{mg}$ progesterone in oil. On Day 7 various groups of mice were treated differently. Group 1 received a single subcutaneous injection of $20 \mathrm{ng}$ oestradiol$17 \beta$ in propylene glycol. Group 2 was given, at laparotomy, an injection into the lumen of one uterine horn of $0.005 \mathrm{ml} 2.5 \mathrm{mM}$-dbcAMP (Boehringer, Mannheim) in phosphate-buffered saline (PBS). In Group 3 the same treatment was applied but, $5 \mathrm{~min}$ before laparotomy, the mice received an intraperitoneal injection of $2 \mathrm{mg}$ theophylline (Merck) in PBS. The animals of Group 4 received an intraluminal injection of 2.5 mM-AMP (Boehringer, Mannheim) in PBS, whereas those of Group 5 were injected with the same volume of PBS alone.

All the mice were injected intravenously with $0.1 \mathrm{ml} 1 \%$ pontamine blue in $0.9 \% \mathrm{NaCl} 5 \mathrm{~min}$ before being killed. Because of the delayed implantation reactions observed after treatment with dbcAMP (Webb, 1975), animals in Group 1 were killed on Day 8 and those in the other groups on Day 9. If there were no blue areas observed at autopsy, the uterine horns were flushed with $0.9 \% \mathrm{NaCl}$ to recover free blastocysts for confirmation of conception.

Segments of uterine horns with implantation sites were recorded and fixed in Bouin's fluid. The serial sections of such areas taken from mice in Groups 1,2 and 4 showed that each contained blastocysts.

Results were examined by the factorial method or Yate's correction for the $\chi^{2}$ test to correct for the low numbers.

\section{Results}

These are given in Table 1. As previously reported (Webb, 1975; Holmes \& Bergström, 1975, 1976), dbcAMP was able to induce implantation. This effect was not significantly altered by giving theophylline with dbcAMP. AMP was also effective for inducing implantation. 
Table 1. The effects of dibutyryl cyclic AMP (dbcAMP) and AMP on the implantation rate of delayed blastocysts in mice

No. of mice with implantation sites

\begin{tabular}{|c|c|c|c|c|c|}
\hline \multirow[b]{2}{*}{ Group } & \multirow[b]{2}{*}{ Treatment $\dagger$} & \multirow[b]{2}{*}{ No. of mice } & \multirow[b]{2}{*}{ Total } & \multirow[b]{2}{*}{$\begin{array}{l}\text { Injected } \\
\text { horn }\end{array}$} & \multirow[b]{2}{*}{$\begin{array}{c}\text { Contralateral } \\
\text { horn }\end{array}$} \\
\hline & & & & & \\
\hline 1 & $20 \mathrm{ng}$ Oestradiol- $17 \beta$ & $14(5)$ & $13^{* *}$ & - & - \\
\hline 2 & $2.5 \mathrm{mM}$-dbcAMP & $14(13)$ & 6 & 5 & 3 \\
\hline \multirow[t]{2}{*}{3} & $2.5 \mathrm{~mm}-\mathrm{dbcAMP}+2 \mathrm{mg}$ & & & & \\
\hline & theophylline & $12(14)$ & 3 & $\mathbf{0}$ & 3 \\
\hline 4 & $2.5 \mathrm{mM}-\mathrm{AMP}$ & $14(12)$ & 8 & 7 & 2 \\
\hline 5 & PBS alone & $12(12)$ & $1^{*}$ & 1 & $\mathbf{0}$ \\
\hline
\end{tabular}

* Significantly different from Groups 2 and $4, P<0.02$.

** Significantly different from all other groups, $P<0.001$.

$\dagger$ Oestradiol was injected s.c. in propylene glycol, other treatments were given by intrauterine injection in phosphate-buffered saline (PBS); theophylline was given i.p. in PBS, 5 min before laparotomy.

$\ddagger$ Only animals with implantation sites or from which free blastocysts could be recovered were considered; the nos in parentheses indicate females which mated but did not yield blastocysts.

\section{Discussion}

It could be argued that the action of AMP was due to its local conversion into cyclic AMP. However, the apparent lack of efficiency of theophylline would be against this interpretation since this compound is known to increase intracellular cAMP levels by inhibiting phosphodiesterase (Robison et al., 1968).

The onset of implantation depends on subtle changes taking place at the interface between the trophoblast and the apical membrane of uterine epithelial cells surrounding the egg (Finn \& Porter, 1975) and under normal conditions these modifications are elicited by 'nidatory' oestrogen. Nucleotides, acting together with uterine distension, may be capable of inducing similar effects and thus allowing implantation to proceed. Holmes \& Bergström (1975) have shown that intrauterine injection of propylene glycol results in a high rate of implantation of delayed blastocysts, but even if uterine distension is involved it cannot account for the implantation reactions occurring in the contralateral horn in the present experiments (see Table 1).

At the start of normal implantation the intrauterine lumen is closed and the antimesometrial epithelial cells are closely apposed to the trophoblastic layer of the egg (Finn \& Porter, 1975). It is therefore surprising that, in experiments involving intrauterine injections which obviously disrupt this arrangement, implantation should occur at all.

F. L. is 'chercheur qualifié' at the Belgian FNRS. This work was supported by a grant from the Belgian FRSM.

\section{References}

Finn, C.A. \& Porter, D.G. (1975) The Uterus. Handbook in Reproductive Biology. Elek Science, London.

Holmes, P.V. \& Bergström, S. (1975) Induction of blastocyst implantation in mice by cyclic AMP. $J$. Reprod. Fert. 43, 329-332.

Holmes, P.V. \& Bergström, S. (1976) Cyclic adenosine monophosphate-induced changes in the surface morphology of diapausing blastocysts and the effects on implantation. Am. J. Obstet. Gynec. 124, 301-306.

Mogla, S. \& Prasad, M.R.N. (1970) Stimulation of RNA synthesis in the blastocyst and uterus of the rat by adenosine 3' 5 '-monophosphate (cyclic AMP). $J$. Reprod. Fert. 23, 327-329.
Robison, G.A., Butcher, R.W. \& Sutherland, E.W. (1968) Cyclic AMP. A, Rev. Biochem. 37, 149-174.

Rosenfeld, M.G. \& O'Malley, B.W. (1970) Steroid hormones: effects on adenyl cyclase activity and adenosine $3^{\prime} 5^{\prime}$-monophosphate in target tissue. Science, N. Y. 168, 253-255.

Smith, D.M. \& Biggers, J.D. (1968) The oestrogen requirement for implantation and the effect of its dose on the implantation response in the mouse. J. Endocr. 41, 1-9.

WeBB, F.T.G. (1975) Implantation in ovariectomized mice treated with dibutyryl adenosine 3'5'-monophosphate (dibutyryl cyclic AMP). J. Reprod. Fert. 42, 511-517. 